\title{
DIREITOS FUNDAMENTAIS E POLÍTICAS PÚBLICAS: A ILEGITIMIDADE CONSTITUCIONAL DA DÍVIDA PÚBLICA FEDERAL
}

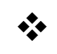 \\ Andreia Filianoti Gasparini \\ Universidade Federal da Fronteira Sul - UFFS - Brasil \\ Leandro Godois \\ Universidade Federal da Fronteira Sul - UFFS - Brasil

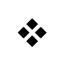

\begin{abstract}
Resumo
A proposta do presente artigo é analisar em que medida o fundamentalismo do superávit primário afeta a concretização dos direitos fundamentais sociais. A hipótese que serve de norte à presente análise é a de que o Estado brasileiro está estruturado para propiciar lucro ao capital financeiro e não para garantir a concretização dos direitos fundamentais sociais previstos na Constituição Federal de 1988. Para tanto, sob uma perspectiva de prioridade econômica e fiscal, buscamos mensurar o impacto das despesas com o serviço e o refinanciamento da dívida pública no Orçamento Geral da União, confrontando-as com os gastos em saúde, educação e assistência social. A conclusão possível é a de que, independentemente da concepção ideológica do governo, o Estado brasileiro se encontra capturado pelo capital financeiro, prejudicando seriamente a concretização dos direitos fundamentais sociais. O objetivo é incitar o debate sobre a dívida pública brasileira a partir de um enfoque interdisciplinar, demonstrando a partir de elementos econômicos e fiscais o descumprimento do compromisso social estatuído na Constituição Federal.
\end{abstract}

Palavras-chave: Direitos Fundamentais Sociais. Dívida Pública.

\section{Considerações iniciais}

Está disseminado no senso comum do cidadão brasileiro a ideia de que a escassez de recursos para investimentos em saúde, educação e distribuição de renda, está vinculada à corrupção, à má gestão e à ineficiência do Estado.

Por certo que esses problemas são de extrema gravidade, merecendo especial atenção, mas nem de longe constituem as principais causas da insuficiência de recursos para os gastos sociais.

Pouco ou nada se fala sobre a significativa parcela do Orçamento da União, literalmente tragada pelos gastos com juros e amortizações da dívida pública federal, em sentido diametralmente oposto à proposta constitucional emancipatória.

A Constituição Federal de 1988 estabeleceu sob a responsabilidade do Estado brasileiro uma gama de direitos sociais, com o fim de dar suporte às aspirações fundamentais 
de "construir uma sociedade livre, justa e solidária" e "erradicar a pobreza e a marginalização e reduzir as desigualdades sociais e regionais".

Contudo, em uma economia capitalista e monetizada, o fornecimento de prestações ou serviços têm um preço, a ser pago em moeda (TIMM, 2013). Cabe salientar que não somente os direitos sociais necessitam de atuação positiva do Estado, mas a própria garantia de direitos ditos negativos, ou de abstenção, a exemplo do sistema de garantias ao direito de propriedade (registros públicos, poder judiciário, etc.). O grande dilema dos Estados modernos, entretanto, é financiar o bem estar.

O financiamento do Estado se faz pela via da tributação, arrecadando impostos, taxas e contribuições sociais, sendo o déficit financiado por intermédio da dívida pública interna (em moeda nacional) ou externa (em moeda estrangeira).

Ao contrário do que se possa - apressada e ingenuamente - imaginar, a evolução da dívida pública ao longo da história não tem servido para financiar os gastos sociais ou a infraestrutura, mas, pelo contrário, tem sistematicamente absorvido recursos públicos das áreas mais fundamentais.

Não há dúvida de que essa (des)orientação do Estado para garantir seguidos superávits primários e a sólida remuneração do capital rentista afeta a condição de factibilidade dos direitos sociais, dada a escassez de recursos. A hipótese central deste estudo é de que a dívida pública constitui obstáculo à efetivação dos direitos fundamentais sociais e, portanto, contraria as metas e objetivos delineados na Constituição Federal.

Para evidenciar esse cenário, confrontamos os gastos totais com a dívida pública e a execução orçamentária relativa às funções "educação", "assistência social" e "saúde", as três áreas centrais do gasto social.

Iniciamos pela contextualização dos marcos teóricos constitucionais, tangenciando o dilema de como financiar o bem estar. No tópico seguinte, aprofundamos a discussão da orientação do Estado brasileiro quanto à arrecadação e o gasto público. No terceiro e último item, apresentamos alguns dados sobre a dívida pública e os gastos sociais, buscando evidenciar a dimensão assumida pelo endividamento no Orçamento Geral da União. Finalizamos propondo um arremate reflexivo à proposta do presente escorço teórico.

\section{Constituição e direitos fundamentais: o dilema de como financiar o bem estar}

A Constituição Federal de 1988 inscreveu o Estado brasileiro no marco de uma economia capitalista, mas de orientação social, mesclando o constitucionalismo liberal, 
associado ao dever de abstenção do Estado, e o constitucionalismo comunitário, identificado com o dever de ação, por meio de prestações positivas a serem executadas pelo Estado (CITTADINO, 2013).

Nossa Magna Carta converteu em compromisso formal do Estado a esperança de uma vida melhor a todos os brasileiros. A Constituição de 1988 é um programa emancipatório, ou, no dizer de Bolzan de Morais (2008), um "projeto civilizatório". O caráter emancipatório da Carta Constitucional brasileira parte do pressuposto de uma Teoria da Constituição dirigente, ou autossuficiente, identificada com a crença de que é possível - ou suficiente - uma Constituição para implementar a mudança na sociedade, transformando a realidade apenas com dispositivos constitucionais (BERCOVICI, 2004).

$\mathrm{Na}$ base desse projeto estão os direitos fundamentais, aqueles direitos que compõem um núcleo duro e intangível de garantias essenciais - no sentido filosófico - dos seres humanos, garantindo-lhes condições mínimas de vida e de desenvolvimento de forma digna. Os direitos fundamentais "são os princípios que resumem a concepção do mundo e informam a ideologia política de cada ordenamento jurídico" (SILVA, 2009, p. 176).

Para nossa análise, direitos fundamentais tem a ver com o rol de direitos inscritos como tal na Constituição Federal, conjunto no qual se inserem os direitos sociais que "são considerados típicos direitos a prestações e apontam para ações fáticas ou ações normativas por parte do Estado" (CITTADINO, 2013, p. 49). Os direitos fundamentais albergam, enfim, as liberdades em relação ao Estado (liberdades negativas), as liberdades no Estado (liberdades políticas) e as liberdades por meio do Estado (direitos de igualdade), conforme classificação de Bobbio (2004).

Direitos fundamentais sociais, portanto, são aqueles inscritos no art. $6^{\circ}$ da Constituição Federal (a educação, a saúde, a alimentação, o trabalho, a moradia, o transporte, o lazer, a segurança, a previdência social, a proteção à maternidade e à infância e a assistência aos desamparados), vetores de um projeto de ampla emancipação.

A meta constitucional emancipatória está expressa nos fundamentos da República do art. $1^{\circ}$ do texto constitucional ("cidadania", "dignidade da pessoa humana" e "valor social do trabalho'), o que é reforçado nos objetivos fundamentais do art. $3^{\circ}$, de "construir uma sociedade livre, justa e solidária" (inciso I); "erradicar a pobreza e a marginalização e reduzir as desigualdades sociais e regionais" (inciso III); "promover o bem de todos, sem preconceitos de origem, raça, sexo, cor, idade e quaisquer outras formas de discriminação (inciso IV)". 
A nosso sentir, o marco constitucional emancipatório pode ser sintetizado no art. $7^{\circ}$, IV da $\mathrm{CF}$, que garante ao trabalhador

salário mínimo, fixado em lei, nacionalmente unificado, capaz de atender a suas necessidades vitais básicas e às de sua família com moradia, alimentação, educação, saúde, lazer, vestuário, higiene, transporte e previdência social, com reajustes periódicos que lhe preservem o poder aquisitivo, sendo vedada sua vinculação para qualquer fim. (grifos adicionados)

Enfim, os direitos sociais são o núcleo duro do projeto constitucional emancipatório.

Noutro norte, a ordem econômica se caracteriza pela administração da escassez, impondo às Constituições a necessidade de estabelecer prioridades, pois os direitos sociais exigem uma ação positiva (prestacional) do Estado, esbarrando na limitação dos recursos orçamentários. Enfim, a Constituição não tem o condão de gerar recursos por mágica ou decreto. Assim, a efetivação dos direitos fundamentais sociais somente será alcançada com um sistema tributário justo e eficiente, e uma alocação orçamentária responsável dos recursos (CALIENDO, 2013).

Nesse cenário, o princípio da "reserva do possível" - oriundo do direito alemão (vorbehalt des möglichen) - é a fronteira material do poder do Estado de concretizar os direitos fundamentais e pode ser de ordem fática (falta de recursos), ou jurídica (falta de orçamento ou programação financeira), como observa Caliendo (2013).

Eliminada, a priori, a problemática opção pela emissão de moeda (seigniorage), dados seus nefastos efeitos inflacionários, são duas as principais formas de um Estado financiar suas despesas: por meio de tributos, ou por meio de dívidas. E o tributo é uma solução infinitamente melhor, tanto em termos de justiça social, quanto de eficácia (PIKETTY, 2014, p. 526).

A arrecadação tributária pode ser direta ou indireta: direta quando incide sobre renda e patrimônio e indireta quando incide sobre produção e consumo (bens e serviços). Os tributos diretos tendem a ser progressivos, a exemplo do Imposto de Renda, cuja alíquota é aplicada proporcionalmente à renda de cada contribuinte (quanto maior a renda do contribuinte, maior o imposto devido). Já os tributos indiretos, sobre a produção e o consumo (ICMS, por exemplo), tendem a ser regressivos, isto é, afetam mais as camadas mais necessitadas, pois, independentemente da renda, alcançam ricos e pobres com idêntica avidez.

Nesse contexto, talvez o grande dilema do Estado brasileiro não seja tanto a escassez de recursos, mas sim a orientação das despesas, convolando-se a dívida pública em óbice intransponível à efetivação dos direitos fundamentais. É para o serviço e a rolagem da dívida 
que são carreados os limitados recursos necessários para garantir a concretização de um nível mínimo de bem estar, o chamado "mínimo existencial", o núcleo duro e essencial dos direitos fundamentais.

\section{Dívida pública e direitos fundamentais: quem tributar e para quem transferir?}

Como pressuposto de nossa análise não basta esmiuçar a despesa orçamentária (como se gasta), mas, antes de tudo, é fundamental delimitar como o Estado brasileiro arrecada (de quem se arrecada).

Nesse sentido, dois problemas são centrais na crise do projeto do Estado brasileiro: em primeiro lugar se invertem as fontes arrecadatórias e, depois, as prioridades orçamentárias. Tributa-se o consumo e a renda do trabalho e transfere-se renda ao capital financeiro. Financiar a dívida é do interesse de quem tem meios para emprestar ao Estado, mas seria melhor ao Estado - e às pessoas - taxar os ricos, do que pegar dinheiro emprestado deles (PIKETY, 2014, p. 526)

Conforme levantamento do IPEA (2011), a regressividade persistente da tributação brasileira fica evidenciada em uma análise da carga tributária incidente sobre a renda total, nos períodos de 2002-2003 e 2008-2009. Os dados coletados para o período 2002-2003 apresentam por resultado a regressividade continuada da carga tributária total: nos $10 \%$ mais pobres a carga tributária atinge cerca de $30 \%$ da renda, caindo continuamente, até representar, nos $10 \%$ mais ricos, $12 \%$. As alterações ocorridas entre 2008-2009 são pouco expressivas, observando-se, de um lado, uma diminuição tênue na incidência da tributação indireta entre 1 e 2 pontos percentuais e, de outro, um incremento, também marginal, na tributação direta de 0,5 ponto percentual. Logo, a carga tributária total sobre as famílias e seu perfil distributivo pouco se alteram, e os índices de progressividade dos tributos diretos e indiretos em 2003 e 2009 permanecem muito semelhantes.

A regressividade do sistema tributário brasileiro - ou seja, a carga excessiva que os impostos representam na renda das camadas pobres e de renda média da população - deve-se aos tributos indiretos. Apesar dessa regressividade na tributação indireta não diferir radicalmente da realidade internacional, a carga dos tributos indiretos na arrecadação tributária brasileira aumenta o seu efeito de concentração de renda (GAIGER, 2013). Em resumo, quanto menor a renda do brasileiro, mais comprometida com o pagamento de tributos. E os tributos indiretos respondem por, aproximadamente, $60 \%$ da receita tributária do Estado brasileiro (ALVES, 2013, p. 84). 
A política social dos anos 2000, centrada nas camadas pobres e intermediárias de renda, buscou corrigir a regressividade do sistema tributário mediante o gasto social progressivo. Antes de uma reforma tributária - processo que demanda um esforço político concentrado e de médio prazo -, a atuação da política social buscou contornar o problema da injustiça tributária com a justiça social. Compreendendo a equidade fiscal como uma relação abrangente entre arrecadação e gasto público - e, portanto, para além da ótica da tributação -, essa perspectiva introduz novos olhares sobre como operar políticas públicas necessárias à consolidação dos direitos sociais e constitucionais (IPEA, 2011).

Entretanto essa reorientação não implicou grandes mudanças no perfil do gasto público. Observando-se a percentagem destinada pelo Orçamento Geral da União (OGU) ao pagamento dos encargos da dívida pública, em comparação aos investimentos em educação, saúde e assistência social, percebe-se claramente que a prioridade do Estado é a dívida pública e o mercado, e não o investimento em políticas sociais.

Os dados econômicos e orçamentários que a seguir vão esmiuçados permitem afirmar que esse não é um problema de orientação ideológica - ou, “de governo" - mas sim, um dilema persistente, decorrente da necessidade de se manter a estabilidade do mercado. $\mathrm{Ou}$ seja, o governo compra, a um altíssimo custo, a aprovação do capital financeiro, tornando-se refém das agências de rating.

As elevadas taxas de juros, fixadas pelo Comitê de Política Monetária (Copom) do Banco Central do Brasil, resultam em enorme transferência de renda da sociedade - coletada, sobretudo, dos mais pobres - para uma parcela minoritária da população, detentora da riqueza financeira.

A corriqueira e ineficiente tentativa de conter a inflação aumentando os juros básicos da economia, como se o problema fosse o consumo, produz efeitos nefastos na dívida pública brasileira. Em decorrência desse processo histórico foi se estabelecendo um padrão de acumulação baseado nos ganhos financeiros consistentes e de curto prazo, fortemente favorável aos detentores da riqueza financeira, em detrimento dos demais segmentos da sociedade. Por outro lado, a possibilidade de retorno garantido, e em níveis elevados, das aplicações em títulos públicos tornava a opção por investimentos produtivos uma alternativa pouco atrativa (LOPREATO, 2014).

O maior crescimento econômico com alguma distribuição de renda, observado na segunda metade dos anos 2000, encobriu, de alguma forma, a manutenção desta lógica rentista. 
Contudo, garantir crescimento econômico e desenvolvimento social exige que se avance na construção de uma nova ordem para o sistema financeiro, em especial no que se refere à redução dos juros básicos e do spread bancário (diferença entre a taxa de juros que o banco paga para captar recursos e a taxa que ele cobra nos empréstimos). Para que tenham efeitos positivos, as medidas devem orientar-se pela diretriz de alavancar recursos para o investimento produtivo, desmobilizando aplicações especulativas. Ademais, é fundamental que se adotem medidas consistentes para conter os gastos com a dívida pública, de modo a liberar recursos para o Estado investir em infraestrutura econômica e social (DIEESE, 2012).

Para fazer frente às intermináveis despesas com os juros e a rolagem da dívida, o governo federal busca, de um lado, ampliar continuamente as receitas com arrecadação de tributos e, de outro lado, comprimir os gastos públicos não financeiros, tais como, aqueles com educação, saúde, assistência social, etc. Nestes termos, os mais pobres são duplamente atingidos: pela tributação e pela contração de gastos sociais. Daí porque o fundamentalismo do superávit primário tende a contribuir para a aceleração do processo de geração de desigualdade.

Segundo relatório final da Comissão Parlamentar de Inquérito (CPI) da Dívida Pública, o aumento da dívida brasileira tem relação direta com as altas taxas de juros, processo que se agravou com o Plano Real. O Plano Real sustentou-se, inicialmente, na grande entrada de capital estrangeiro para o financiamento dos déficits em transações correntes, sendo que o principal instrumento de atração de capitais era a alta taxa de juros interna, que implicava indiretamente no aumento da dívida pública. Enfim, o crescimento da dívida interna foi projetado pelas taxas de juros brasileiras, historicamente altas. A elevada taxa de juros foi o principal responsável pelo crescimento da dívida interna desde o começo do Plano Real (BRASIL, 2010a).

No Brasil, o Banco Central determina as taxas de juros que constituem instrumento de política monetária, sendo que essas mesmas taxas remuneram uma fatia importante da dívida pública federal. Isso se deve, principalmente, a um processo histórico de espiral inflacionária, que produziu uma cultura financeira incomum de rendimento sólido em curto prazo. Como consequência dessa cultura inflacionária, um grande percentual dos títulos federais são indexados à taxa overnight (Selic), de modo que qualquer aumento nas taxas de juros resulta em um aumento direto do estoque total da dívida pública (BRASIL, 2010a; LOPREATO, 2014).

Algumas medidas já foram implantadas na tentativa de mudar a estrutura da dívida pública brasileira. De 2000 a 2015, a participação percentual da taxa SELIC (Sistema Especial 
de Liquidação e Custódia de Títulos Públicos), no estoque dos títulos públicos federais reduziu de 52,7\% em 2000, para 15,7\%, em julho de 2015. A mudança da remuneração da poupança, implementada em 2012, atrelando seus rendimentos à variação da taxa SELIC, foi uma tentativa de minorar o impacto da redução dos juros básicos da economia na rolagem da dívida pública federal, evitando que a redução da taxa ocasionasse a migração dos recursos para a poupança, dificultando a rolagem da dívida. Isso possibilitou alguma autonomia para a autoridade monetária em fixar a taxa de juros de acordo com a política monetária (LOPREATO, 2014). A medida visava, em última análise, permitir a política de redução da SELIC e um maior investimento nos gastos sociais (DIEESE, 2012). Entretanto, ainda modesta e insuficiente.

Além das mudanças no contexto macroeconômico que buscaram reduzir o impacto dos juros na dívida pública, evidenciam-se tendências da intervenção redistributiva do Estado brasileiro no sistema tributário. A regressividade do sistema tributário (gerador de desigualdades), tem sido compensada pela progressividade do gasto social, notadamente os com educação e saúde públicas e as despesas previdenciária e assistencial. O redirecionamento do gasto social para os estratos de renda mais baixos se aprofundou, sobretudo a partir dos anos 2000 (GAIGER, 2013; IPEA, 2012).

No entanto, essa reorientação da engrenagem estatal não é confiável ou persistente e, ademais, encontra natural - e severa - resistência.

A celeuma em torno da extinta Contribuição Provisória sobre a Movimentação Financeira (CPMF) é um evidência concreta da resistência às políticas tendentes a inverter a lógica vigente. A CPMF é um tributo isonômico, talvez o mais justo já vigente no Brasil, pois efetivo em sua base de incidência (movimentação financeira), incidindo em maior medida sobre a renda do capital do que sobre a renda do trabalho; e, ademais, claramente progressivo (quanto maior a movimentação, maior a fatia abocanhada pelo fisco). Além disso, tinha a finalidade específica de garantir o direito fundamental à saúde. Embora de interesse dos governos acabou extinta porque não interessava aos setores econômicos mais afetados por sua base de incidência.

Se parcela da sociedade rechaça mudanças, o Estado também não parece efetivamente comprometido com a reorientação das políticas públicas ao programa constitucional.

As ditas "contribuições sociais" (art. 149 da CF/88), cuja receita deveria - em tese financiar a seguridade social (saúde, previdência e assistência social), terminaram propiciando apenas mais uma fonte de receita para o místico ajuste fiscal. A DRU - Desvinculação das 
Receitas da União, criada na década de 90, permite aos governos usar livremente os recursos provenientes dessas contribuições sociais, inclusive para garantir a (re)produção ascética das fontes de custeio destinadas ao superávit primário.

Ainda neste estado de coisas, a Lei de Responsabilidade Fiscal (LRF), corrobora e valida legalmente o misticismo em torno do superávit primário. A Lei Complementar n. 101 determinou o controle de gastos da União, dos Estados e dos Municípios, conforme a capacidade de arrecadação tributária destes entes federativos. Ainda que a LRF tenha impossibilitado os gastos públicos que ultrapassassem a arrecadação tributária, verifica-se, na prática, que é apenas mais um mecanismo de corte das despesas sociais para priorizar o pagamento de juros da dívida pública. Há rigor nas despesas com pessoal, investimento ou custeio, mas, por outro lado, uma elasticidade ética bastante grande com a dívida pública.

Enfim, essas situações apenas evidenciam o quão complicado é propor ou implementar qualquer política que importe em progressividade fiscal ou redirecionamento dos orçamentos para os gastos sociais.

\section{Dívida pública versus gastos sociais: a (des)orientação orçamentária do Estado brasileiro}

O grau de orientação do Estado no sentido de determinada prioridade - em tese pode ser mensurado pela quantidade de recursos que destina a esse determinado fim. Enfim, para identificar as prioridades é preciso ver como o Estado gasta os recursos que arrecada.

A ideia deste tópico é ilustrar com dados econômicos e orçamentários a representatividade da dívida pública e o descumprimento do programa constitucional dos direitos sociais.

A Dívida Pública Mobiliária Federal Interna (DPMFi) é a principal fonte de financiamento do déficit estatal, representando o instrumento básico de gestão do déficit orçamentário, determinando, portanto, a evolução da composição, dos prazos dos e riscos da dívida de responsabilidade do Governo Central (BRASIL, 2010a). Ademais, constitui foco essencial de nossa análise, pois melhor representa a transferência direta de recurso captados da coletividade ao capital financeiro.

Buscamos, dentro das limitações do presente artigo, analisar a dívida pública sob dois enfoques, o econômico e o orçamentário, a fim de determinar como a dívida pública interna afeta os gastos sociais e como isso se orienta com os objetivos e metas constitucionais. 
De início, é necessário esmiuçar brevemente o que se entende por dívida pública. A dívida pública nacional abrange a dívida interna e a externa, da administração direta e indireta, nas esferas federal, estadual e municipal, podendo ainda ser, quanto à forma, monetária, mobiliária e contratual. A Dívida Pública Federal (DPF) é composta pela dívida adquirida pelo Tesouro Nacional para suportar o déficit orçamentário do governo federal, alcançando o serviço e o refinanciamento da própria dívida e as operações financeiras contratadas a fim de cumprir finalidades determinadas. No que diz respeito à forma, o endividamento pode se realizar: por meio de contratos, denominada "dívida contratual", em geral estabelecida com instituições multilaterais (Banco Mundial, bancos privados, agências internacionais governamentais, etc.); ou pela emissão de títulos públicos, conhecida como dívida mobiliária. A Dívida Pública Mobiliária Federal interna (DPMFi) é movimentada no mercado nacional, operacionalizada em real e "captada" pela emissão de títulos públicos, sendo a parcela mais significativa da dívida brasileira.

O pagamento dos juros e amortizações da dívida pode ocorrer pela contratação de uma nova dívida, expandindo o estoque de títulos públicos em mercado (mecanismo conhecido como "rolagem" da dívida); pela expansão da base monetária (seigniorage, sujeita a ameaça de pressão inflacionária); ou pela austeridade fiscal do Estado visando ampliação do superávit primário.

O superávit primário consiste no saldo entre as receitas da União e as despesas do governo antes do pagamento dos juros da dívida pública. Ou seja, é a economia feita pelo governo para pagar o chamado "serviço da dívida". Portanto, após o pagamento dos juros, não resta nada dos recursos economizados. O superávit primário é um poderoso mecanismo de concentração da renda, na medida em que ampla parcela da arrecadação tributária de toda sociedade transfere-se aos detentores dos títulos da dívida pública, que na maioria $(72,8 \%)$ são instituições financeiras, fundos de investimentos, investidores não residentes e seguradoras (DIEESE, 2015).

Segundo Relatório Anual da Dívida Pública, no ano de 2015, 25\% da DPMFi estava em poder das instituições financeiras; 19,6\% de Fundos de Investimento; 18,8\% de "nãoresidentes"; 21,4\% de Fundos de Previdência, 5,8\% do Governo; 4,6\% de seguradoras e 4,9\% de "outros" detentores (BRASIL, 2016b, p. 45).

A fatia orçamentária tragada pelo capital financeiro não é pequena. E, no caso brasileiro, há um sério agravante: parcela significativa da dívida está atrelada à taxa SELIC (Sistema Especial de Liquidação e Custódia), de maneira que o estoque e os encargos são diretamente afetados pela política monetária. Eleva-se a SELIC, aumenta-se a dívida.

Barbarói, Santa Cruz do Sul, Edição Especial n.47, p.<251-270>, jan./jun. 2016 
Em 2014, a União gastou R 9978 bilhões com o pagamento de juros e amortizações da dívida pública, o equivalente a 45,11\% de todo o orçamento. Ainda, no mesmo ano, 45,7\% dos títulos públicos eram remunerados com base na taxa SELIC. A questão central, portanto, é se as elevações da SELIC favorecem o controle inflacionário ou a remuneração do capital financeiro (DIEESE, 2015).

O fundamentalismo do superávit primário serve para espremer o direito de muitos em troca de garantir a remuneração de poucos.

O superávit primário, por exemplo, além de importante ferramenta da política macroeconômica para conter a inflação deve ser interpretado como mecanismo de concentração da renda, na medida em que é destinado integralmente ao pagamento da dívida. O superávit primário, produto do esforço de austeridade fiscal do Estado, pode, assim, também ser compreendido como arrecadação tributária de toda sociedade transferida aos poucos detentores dos títulos da dívida pública, e não apenas como elemento de credibilidade assegurado pelo Estado diante do investidor nacional e estrangeiro (DIEESE, 2015, p. 3).

A situação da dívida pública não é algo novo ou incomum, mas, ao contrário, uma ação que se agrava ano após ano e, pior, se consolida como processo histórico. A (des)orientação capitalista do Estado brasileiro é um movimento histórico e consistente.

Em 2015, o estoque da DPMFi apresentou crescimento de $\mathrm{R} \$ 466,6$ bilhões, representando um acréscimo de $21,4 \%$ em relação ao montante do ano anterior, sendo $\mathrm{R} \$$ 316,7 bilhões decorrentes da apropriação de juros. O percentual de refinanciamento da DPMFi foi de 119,95\% em 2015, 41,38\% maior em relação ao ano anterior. O percentual de refinanciamento representa a razão entre emissões e resgates (principal e juros), ou seja, evidencia o aumento do estoque da dívida (BRASIL, 2016b).

$\mathrm{Na}$ avaliação da capacidade de solvência de um País, o indicador mais importante é a relação dívida/PIB e a forma como ela evolui. Assim, o importante na relação dívida/PIB não é apenas a proporção, mas também a tendência. O problema elementar da dívida brasileira é a instabilidade dessa relação. Isso se deve a vários fatores, como os prazos de vencimento dos títulos (muito curtos) e remuneração garantida aos credores (muito alta). Já, analisando a dívida sob o enfoque orçamentário, vê-se que a composição e o perfil da dívida mobiliária federal são aspectos fundamentais para o entendimento da dinâmica dos números da dívida no Orçamento. Quanto menor o prazo, maior a parcela da dívida total que vence em cada ano, implicando uma necessidade orçamentária maior (BRASIL, 2010a).

Segundo o relatório final da CPI da dívida pública, os valores constantes do Orçamento direcionados à dívida refletem as características do endividamento da União em termos de estoque, perfil e composição, mas não são o melhor parâmetro para se avaliar a 
capacidade de solvência ou a prioridade de alocação de recursos públicos (BRASIL, 2010a, p. 227). Não concordamos com tal assertiva, dado que o orçamento representa a programação de receitas e gastos do setor público, refletindo políticas e prioridades. E, ademais, a evolução e a consistência da dívida na análise de períodos mais longos evidencia que uma parcela significativa dos recursos da sociedade tem sido sistematicamente endereçados para garantir os lucros do capital rentista, prejudicando a produção, o consumo e a justiça social, em absoluto confronto com o programa constitucional.

No entanto, a fim de conferir maior amplitude de análise utilizamos também como referência o PIB, que afere a riqueza produzida em determinado período, que oferece uma perspectiva de como o Estado gastou os recursos arrecadados da sociedade. Em 2000, o estoque de R \$ 556 bilhões da DPMFi representava 47,1\% do Produto Interno Bruto (PIB), ou seja, de toda a riqueza produzida pela economia nacional no mesmo período; em 2009, durante a crise financeira mundial, o estoque alcançou o patamar 61,2\% do PIB; em 2014, o estoque de R \$ 3,30 trilhões representava 59,8\% do PIB. Em julho de 2015 a Dívida Pública Mobiliária Federal interna atingiu 62,9\% do PIB, um percentual historicamente significativo (DIEESE, 2015).

Os dados da dívida pública em relação ao PIB foram brevemente alinhados acima e demonstram o agravamento e a instabilidade da relação dívida/PIB. Resta, então, analisar a dívida pública sob a perspectiva orçamentária/fiscal.

A fim de ilustrar o grau de orientação do Estado no sentido de priorizar a dívida em detrimento do gasto social utilizamos alguns dados da série histórica do orçamento executado por função e por grupo de natureza de despesa, conforme a classificação orçamentária vigente.

O conceito de função vem delineado em Brasil (2010b):

FUNÇÃO: Corresponde a uma classificação orçamentária da despesa, que pode ser traduzida como o maior nível de agregação das diversas áreas de atuação do setor público. A funcão está relacionada com a missãoinstitucional do órgão, por exemplo, cultura, educação, saúde, defesa, que guarda relação com os respectivos Ministérios. (grifos adicionados)

Grupo de Natureza da Despesa (GND), conforme Brasil (2016a),

é a forma de classificação da despesa, empregada na lei orçamentária, composta de seis categorias, a saber: 1-Despesas com Pessoal e Encargos Sociais; 2 - Juros Encargos da Dívida; 3 - Outras Despesas Correntes; 4 - Investimentos; 5 Inversões Financeiras; 6 -Amortização da Dívida.(grifos adicionados) 
Foram utilizados na análise valores do orçamento total executado (despesas pagas), excluídos os restos a pagar. Na apuração dos valores gastos com a dívida foram considerados os grupos de natureza de despesas GND - 2 - Juros e Encargos da Dívida e GND - 6 Amortização da Dívida. Para aferição de gastos sociais foram utilizadas apenas as despesas por função em educação, saúde e assistência social, por considerarmos essas áreas o tripé dos chamados direitos sociais. Optamos por utilizar as três áreas porque suficientemente representativas do gasto social, considerando, ainda, os limites deste artigo. O item "outros" representa todo o universo de despesas não incluídas nas funções educação, saúde e assistência social.

O período de abrangência foi de 2001 a 2015, dado que esse é o período disponível na ferramenta utilizada, o sistema "Siga Brasil", do Senado Federal.

Em 2001, por exemplo, a União gastou com a dívida $\mathrm{R} \$ 326$ bilhões, sendo a despesa total executada em saúde, da ordem de $\mathrm{R} \$ 20$ bilhões, isto é apenas 6,1\% do montante endereçado para a dívida (BRASIL, 2001).

O mesmo movimento se observa nos anos seguintes.

Em 2014, o governo federal gastou R \$ 978 bilhões com juros e amortizações da dívida pública, o que representou $45,1 \%$ de todo o orçamento efetivamente executado no ano. Essa quantia corresponde a 12 vezes o que foi destinado à educação, 11 vezes aos gastos com saúde, ou mais que o dobro dos gastos com a Previdência Social (FATTORELLI, 2015). Em 2015 o governo Federal gastou R $\$ 962$ bilhões com juros e amortizações da dívida pública, em um orçamento de $\mathrm{R} \$ 2,2$ trilhões, o que representou $43,7 \%$ de todo o orçamento executado. Nesse ano, a despesa executada em saúde foi de R $\$ 93$ bilhões, menos de $10 \%$ do montante gastos com juros, encargos, amortizações e refinanciamento da dívida pública (BRASIL, 2015).

Os dados do Orçamento Geral da União (OGU) do período de 2001 a 2015, sintetizados no gráfico abaixo, evidenciam a disparidade entre gasto social e despesas com a dívida pública. 


\section{Gráfico I \\ Orçamento Geral da União - Executado - GND - Função (em R\$ bilhões)}

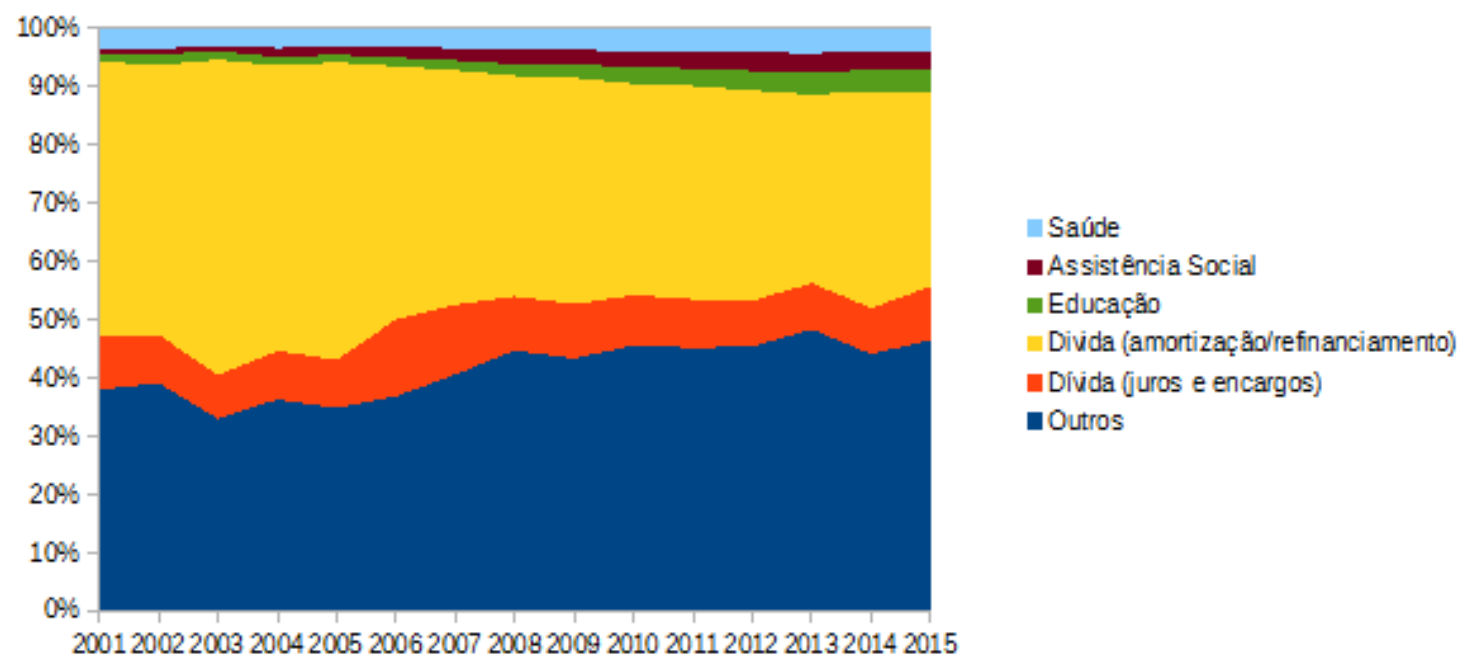

Fonte: Senado - SIGA BRASIL (elaboração própria' ${ }^{1}$ ).

Com base nesses dados é possível perceber que o gasto com amortização e refinanciamento da dívida se reduziu, mas o gasto orçamentário com juros e encargos é consistente. O gasto com juros e encargos da dívida é superior à soma dos gastos em saúde, educação e assistência social em quase todo o período analisado, havendo uma reversão dessa tendência a partir de 2008. De todo modo, é fácil ver que a dívida pública tem abocanhando uma fatia significativa dos recursos orçamentários ao longo dos anos. Por outro lado, ao contrário do que sucede com a dívida, há uma estabilidade na relação entre orçamento total executado e despesas em saúde, e um leve crescimento dos gastos em educação e assistência social, sobretudo a partir de 2006.

O mesmo cenário resta evidenciado pelo gráfico abaixo, elaborado pela Auditoria Cidadã da Dívida (2013), e que deixa clara a evolução da dívida e dos gastos em outras áreas em um período mais amplo (1995 a 2011).

\footnotetext{
${ }^{1}$ Registramos o agradecimento ao colega Jorge Schommer, que auxiliou na elaboração final do gráfico.

Barbarói, Santa Cruz do Sul, Edição Especial n.47, p.<251-270>, jan./jun. 2016
} 


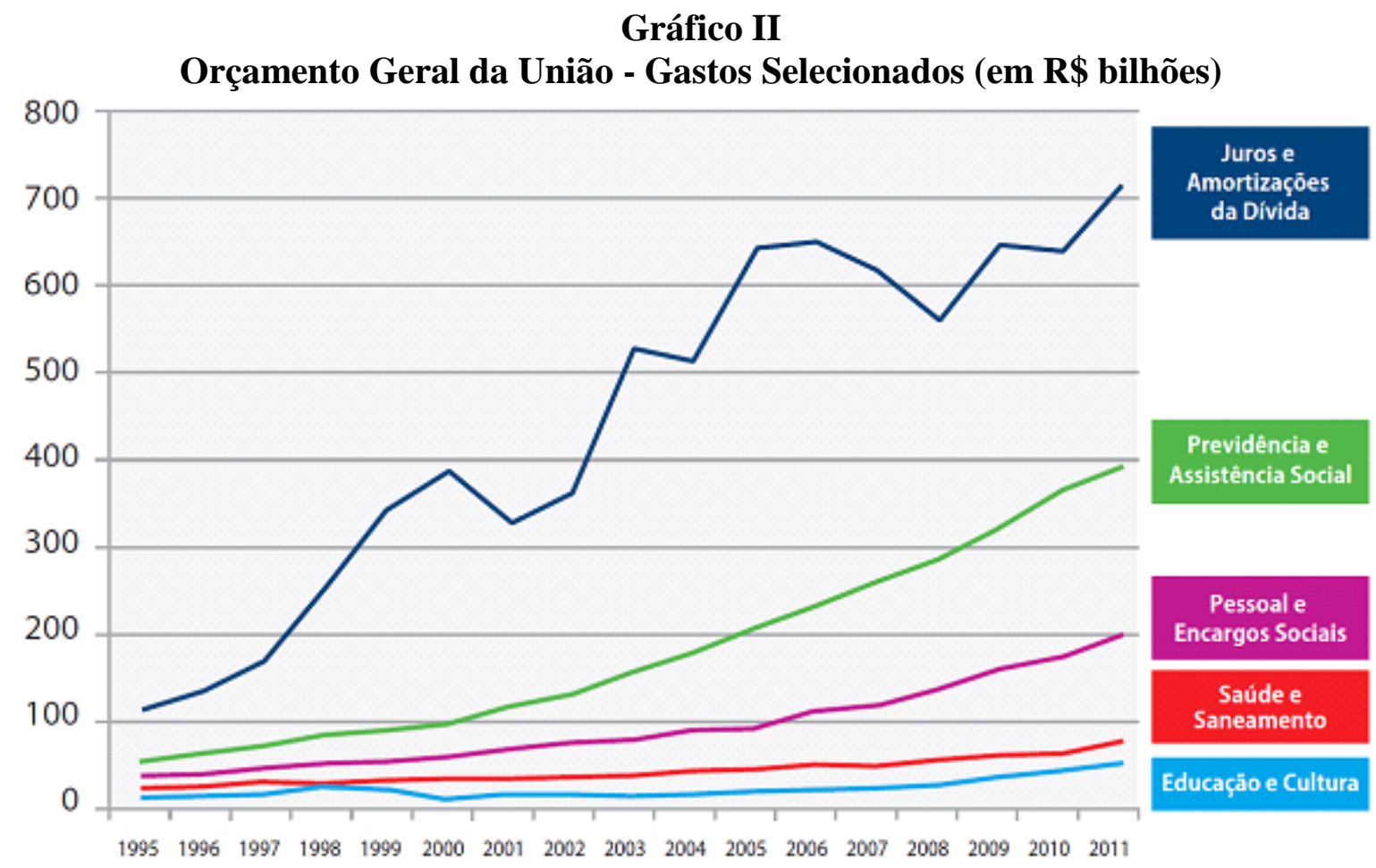

Fonte: Secretaria do Tesouro Nacional - SIAFI

Elaboração: Auditoria Cidadã da Dívida

Importante observar que o período (1995-2011) alcança os dois Governos de Fernando Henrique Cardoso (FHC) e os dois Governos de Luiz Inácio Lula da Silva, o que é importante na verificação da hipótese de que cuida-se de uma política de Estado e não de governo, pois os dados alcançam governos que, a priori, são de orientação ideológica distinta.

\section{Considerações finais}

No Brasil, além da carga de tributos indiretos penalizar as camadas de menor poder aquisitivo, a renda do trabalho é mais tributada do que a renda do capital financeiro (IPEA, 2011). Ou seja, a tributação se concentra nos trabalhadores e o bolo arrecadado, a muito custo, é transferido aos detentores do capital financeiro por meio dos juros sobre a dívida pública. Observa-se então, na prática, uma inversão dos objetivos constitucionais de "construir uma sociedade livre, justa e solidária" e "erradicar a pobreza e a marginalização e reduzir as desigualdades sociais e regionais".

Não é apenas na tributação que o capital financeiro leva vantagem. A situação de principal credor do Estado propicia ao setor financeiro capturar parcela significativa dos recursos arrecadados. Se a tendência natural das leis fundamentais do capitalismo é 
aprofundar a desigualdade (PIKETTY, 2014), no Brasil esse processo tende a ocorrer com maior rapidez.

$\mathrm{Na}$ verdade, o mecanismo de arrecadação e de gasto público se tornou, ao contrário da diretriz constitucional, instrumento de promoção da desigualdade. O Estado brasileiro é uma fábula do abismo social, um Robin Hood às avessas.

O volume de recursos orçamentários endereçados à dívida pública é uma evidência significativa de que os recursos indispensáveis para garantia dos direitos sociais vem sendo sacrificados em favor do serviço e do refinanciamento de uma dívida constitucional e socialmente ilegítima.

Diante desse cenário, a "reserva do possível", ou seja, o princípio das limitações orçamentárias que orienta a defesa do Estado nos reclames jurisdicionalizados dos direitos sociais (judicialização da saúde, por exemplo), soa como escárnio para quem busca no Poder Judiciário a última alternativa para garantir o "mínimo existencial”, um núcleo essencial de bem estar e dignidade.

A má notícia é que não apenas a execução orçamentária se vê cerceada pelo protagonismo do capital financeiro. A tendência jurisprudencial mais recente - no sentido de garantir liberdade ao mercado financeiro para fixar, como bem lhe aprouver, os juros que escorcham e asfixiam o setor produtivo -, evidenciam que o último bastião das promessas constitucionais é mais uma engrenagem estatal a serviço do sistema financeiro.

A redução dos efeitos da desigualdade - e, por conseguinte, a concretização das promessas constitucionais - passa, necessariamente, pela reforma tributária, seja para reduzir a carga que pesa sobre os ombros das camadas mais pobres, seja para propiciar o aumento da arrecadação, por meio de uma tributação mais elevada e efetiva do capital, sobretudo financeiro.

O desafio é pensar e propor alternativas para descolonizar o Estado, ou, pelo menos, diminuir os efeitos da colonização do Estado pelo mercado.

Enquanto o Estado brasileiro permanecer orientado para garantir os lucros do capital financeiro, a promessa constitucional emancipatória não será mais do que isso, uma simples e vazia, promessa. 


\title{
FUNDAMENTAL RIGHTS AND PUBLIC POLICIES: THE CONSTITUTIONAL ILLEGITIMACY OF FEDERAL PUBLIC DEBT
}

\begin{abstract}
The purpose of this article is to analyze to what extent fundamentalism primary surplus affects the achievement of fundamental social rights. The hypothesis that serves north to this analysis is that the Brazilian State is structured to provide income to finance capital and not to ensure the achievement of fundamental social rights under the Federal Constitution of 1988. Thus, from the perspective of economic priority and tax, we seek to measure the impact of the costs of the service and the public debt refinancing in the Federal Budget, confronting them with spending on health, education and social assistance. The possible conclusion is that regardless of the ideological conception of government, the Brazilian State is captured by financial capital, seriously jeopardizing the achievement of fundamental social rights. The aim is to encourage the debate on the Brazilian public debt from an interdisciplinary approach, demonstrating from economic and fiscal elements the failure of social commitment requirements established in the Federal Constitution.
\end{abstract}

Keywords: Social Fundamental Rights. Public debt.

\section{Referências}

ALVES, José Antônio de Oliveira. Dívida pública e a efetivação dos direitos fundamentais. Amazônia em Foco, Castanhal, v.2, n.3, p. 79-97, jul.-dez. 2013. Disponível em: http://revista.fcat.edu.br/index.php/path/article/view/104/66. Acesso em: 12 jun. 2016.

AUDITORIA CIDADÃ DA DÍVIDA. Relatório Específico de Auditoria Cidadã da Dívida n ${ }^{\circ}$ 1/2013. Exame Específico referente à contabilização de parte dos juros nominais como se fossem amortizações. Brasília, 29 mai. 2013. Disponível em:

http://www.auditoriacidada.org.br/wp-content/uploads/2013/11/Parecer-ACD-1-

Vers\%C3\%A3o-29-5-2013-com-anexos.pdf. Acesso em: 19 jun. 2016.

BERCOVICI, Gilberto. Constituição e política: uma relação difícil. Lua Nova, n. 61, 2004. Disponível em: http://www.cedec.org.br/files_pdf/luanova/ln-61.pdf. Acesso em: 10 abr. 2016.

BOBBIO, Norberto. A era dos direitos. Rio de Janeiro: Elsevier, 2004.

BOLZAN DE MORAIS, Jose Luis. Estado Constitucional, Direitos Fundamentais: limites e possibilidades. Porto Alegre: TRF - $4^{\mathrm{a}}$ Região, 2008. (Caderno de Direito Constitucional, módulo 5). Disponível em:

http://www2.trf4.jus.br/trf4/upload/editor/apg_BOLZAN_COMPLETO.pdf. Acesso em: 24 nov. 2015.

BRASIL. Câmara dos Deputados. Relatório final da comissão parlamentar de inquérito destinada a investigar a dívida pública da União, Estados e Municípios, o pagamento de juros da mesma, os beneficiários destes pagamentos e o seu impacto nas políticas sociais e no desenvolvimento sustentável do País. Relator Deputado Pedro Novais. Brasília, 2010. Disponível em: http://www2.camara.leg.br/atividade-legislativa/comissoes/comissoes- 
temporarias/parlamentar-de-inquerito/53a-legislatura-encerradas/cpidivi/relatorio-finalaprovado/relatorio-final-versao-autenticada. Acesso em: 19 jun. 2016.

Constituição da República Federativa do Brasil de 1988. Brasília. Disponível em: http://www.planalto.gov.br/ccivil_03/Constituicao/Constituicao.htm. Acesso em: 19 mar. 2016.

Lei Complementar n. 101, de 4 de maio de 2000. Estabelece normas de finanças públicas voltadas para a responsabilidade na gestão fiscal e dá outras providências. Brasília. Disponível em: http://www.planalto.gov.br/ccivil_03/leis/LCP/Lcp101.htm. Acesso em: 20 jun. 2016.

Ministério do Planejamento, Orçamento e Gestão. Séries históricas de dados e indicadores fiscais. Brasília, 2010. Disponível em: http://www.orcamentofederal.gov.br/informacoes-orcamentarias/estatisticasfiscais/cronograma/anual/Notas_e_metadados_2010.pdf. Acesso em: 18 jun. 2016.

Ministério do Planejamento, Orçamento e Gestão. Glossário. Brasília, 2016. Disponível em: http://www.orcamentofederal.gov.br/glossario-1/gnd-grupo-de-natureza-dadespesa. Acesso em: 20 jun. 2016.

. Senado Federal. SIGA Brasil. LOA 2001 a 2015. Execução Orçamentária por Grupo Natureza de Despesa (GND). Disponível em: http://www8d.senado.gov.br/dwweb/abreDoc.html?docId=684730. Acesso em: 19 jun. 2016.

Senado Federal. SIGA Brasil. LOA 2001 a 2015. Execução Orçamentária por Função. Disponível em: https://www12.senado.leg.br/orcamento/loa?ano=2015\&categoria=4.1.1\&fase=execucao. Acesso em: 19 jun. 2016.

Tesouro Nacional. Relatório anual 2015. Dívida pública federal. Brasília, 2016.

Disponível em: https://www.tesouro.fazenda.gov.br/documents/10180/269444/RAD_Relat\%C3\%B3rio_Anua 1_2015_.pdf/b95e87d0-1546-45e3-b01c-a10d48ec97d8. Acesso em: 19 jun. 2016.

CALIENDO, Paulo. Reserva do possível, direitos fundamentais e tributação. In: SARLET, Ingo Wolfgang; TIMM, Luciano Benetti (orgs.). Direitos fundamentais. Orçamento e "reserva do possível”. 2.ed. Porto Alegre: Livraria do Advogado, 2013, p. 175-186.

CITTADINO, Gisele. Pluralismo, direito e justiça distributiva. Elementos da filosofia constitucional contemporânea. 4.ed. Rio de Janeiro: Lumen Juris, 2013.

DEPARTAMENTO INTERSINDICAL DE ESTATÍSTICA E ESTUDOS

SOCIOECONÔMICOS (DIEESE). Dívida pública brasileira e compressão do orçamento: o que resta aos trabalhadores. Nota técnica n. 148, set. 2015. Disponível em: http://www.dieese.org.br/notatecnica/2012/notaTec111rentismo.pdf. Acesso em: 17 jun. 2016. 
Juros, rentismo e desenvolvimento. Nota técnica n. 111, jun. 2012. Disponível em: http://www.dieese.org.br/notatecnica/2012/notaTec111rentismo.pdf. Acesso em: 17 jun. 2016.

FATTORELLI, Maria Lucia; ÁVILA, Rodrigo. Gastos com a Dívida Pública em 2014 superaram 45\% do Orçamento Federal Executado. Auditoria Cidadã da Dívida. 5 fev. 2015. Disponível em: http://www.auditoriacidada.org.br/blog/2013/06/20/e-por-direitos-auditoriada-divida-ja-confira-o-grafico-do-orcamento-de-2012/. Acesso em: 19 jun. 2016.

GAIGER, Fernando Silveira et al. Equidade Fiscal: impactos distributivos da tributação e do gasto social no Brasil. Centro Internacional de Políticas para o Crescimento Inclusivo (IPCIG). Working Paper n. 221, out. 2013. Brasília: Centro Internacional de Políticas para o Crescimento Inclusivo, 2013. Disponível em: http://www.ipcundp.org/pub/port/OP221PT_Equidade_Fiscal_Impactos_Distributivos_da_Tributacao_e_do_ Gasto_Social_no_Brasil.pdf. Acesso em: 17 jun. 2016.

INSTITUTO DE PESQUISA ECONÔMICA APLICADA (IPEA). Equidade Fiscal no Brasil. Impactos distributivos da tributação e do gasto social. Comunicado n. 92, 19 mai. 2011. Brasília: IPEA, 2011. Disponível em: http://www.ipea.gov.br/portal/images/stories/PDFs/comunicado/110519_comunicadoipea92.p df. Acesso em: 14 jun. 2016.

Gasto Social Federal: prioridade macroeconômica no período 1995-2010.Nota técnica n. 9, set. 2012. Brasília: IPEA, 2012. Disponível em: http://www.ipea.gov.br/agencia/images/stories/PDFs/nota_tecnica/120904_notatecnicadisoc0 9.pdf. Acesso em: 14 jun. 2016.

LOPREATO, Francisco Luiz C. Dívida Pública: o limiar de mudanças? In: CALIXTRE, André Bojikian; BIANCARELLI, André Martins; CINTRA, Marcos Antônio Macedo (Orgs.). Presente e futuro do desenvolvimento brasileiro. Brasília: IPEA, 2014, p. 261-291. Disponível em:

http://www.ipea.gov.br/portal/index.php?option=com_content $\& v i e w=\operatorname{article} \& i d=23279$. Acesso em: 2 mar. 2016.

PIKETTY, Thomas. O capital no século XXI. Rio de Janeiro: Intrínseca, 2014.

SILVA, José Afonso da. Curso de direito constitucional positivo. 32.ed. São Paulo: Malheiros, 2009.

TIMM, Luciano Benetti. Qual a maneira mais eficiente de prover direitos fundamentais: uma perspectiva de direito e economia? In: SARLET, Ingo Wolfgang; TIMM, Luciano Benetti (orgs.). Direitos fundamentais. Orçamento e "reserva do possível". 2.ed. Porto Alegre: Livraria do Advogado, 2013, p. 51-62.

\section{Sobre os autores:}

Andreia Filianoti Gasparini é Defensora Pública. Mestranda em Desenvolvimento e Políticas Públicas pela Universidade Federal da Fronteira Sul - UFFS, campus de Cerro Largo, RS (andreiafg@gmail.com). 
Leandro Godois é Advogado. Mestrando em Desenvolvimento e Políticas Públicas pela Universidade Federal da Fronteira Sul - UFFS, campus de Cerro Largo, RS (leandrogodois@ via-rs.net). 